\title{
WSPÓLNE PODĄŻANIE ZA DZIECKIEM - WSPÓŁPRACA PERSONELU KLUBU DZIECIĘCEGO Z RODZICAMI
}

\section{JOINTLY FOLLOWING THE CHILD - COOPERATION BETWEEN THE STAFF OF A CHILDREN'S CLUB AND PARENTS}

\author{
Beata Kuca ${ }^{1(A, B, C, D, E, F, G)}$ \\ ${ }^{1}$ Dolnośląska Szkoła Wyższa we Wrocławiu
}

\begin{abstract}
Kuca B. (2019). Wspólne podążanie za dzieckiem - współpraca personelu klubu dziecięcego z rodzicami. Rozprawy Społeczne, 13(1), 43-48.
\end{abstract} https://doi.org/10.29316/rs.2019.05
Wkład autorów:
A. Zaplanowanie badań
B. Zebranie danych
C. Dane - analiza i statystyki
D. Interpretacja danych
E. Przygotowanie artykułu
F. Wyszukiwanie i analiza literatury
G. Zebranie funduszy

Tabele: 0

Ryciny: 0

Literatura: 11

Otrzymano: listopad 2018

Zaakceptowano: styczeń 2019

\begin{abstract}
Streszczenie
Oczekiwania względem instytucji wczesnej edukacji i opieki stale się zmieniają. Rodzice czy opiekunowie dzieci poszukują miejsc, które pomogą im w wychowaniu dziecka, niejednokrotnie chcieliby, aby część kompetencji i umiejętności, potrzebnych w dalszym życiu, dziecko zdobyło właśnie w placówkach opieki zbiorowej. Treścią artykułu jest ukazanie korzyści płynących ze współpracy wychowawczyń z rodzicami dzieci uczęszczających do jednego z klubów dziecięcych na Dolnym Śląsku. Artykuł prezentuje opis współpracy personelu placówki z rodzicami dwójki dzieci: Jacka, który miał trudności rozwojowe i problemy w zakresie kontaktów społecznych oraz Małgosi, u której podejrzewany był mutyzm wybiórczy. Jacek uczęszczał do klubu dziecięcego przez okres dwóch lat, natomiast Małgosia przez niespełna rok. W tym czasie pojawiały się różne momenty zwrotne we współpracy personelu z ich rodzicami. Współpraca rodziców z wychowawcami to klucz do harmonijnego rozwoju młodego człowieka, a w przypadku zauważonych trudności w rozwoju oraz codziennym funkcjonowaniu dziecka, współpraca ta wydaje się być szczególnie ważna.
\end{abstract}

Słowa kluczowe: współpraca z rodzicami, instytucja wczesnej edukacji i opieki, żłobek, klub dziecięcy, mutyzm wybiórczy

\section{Summary}

Expectations towards institutions tasked with early education and care are constantly changing. Parents or guardians of children are looking for places that will help them to raise a child, frequently it is exactly in collective care institutions where they would like for the child to acquire some of the competences and skills needed in later life. The meaning of the article is to show the benefits stemming from the cooperation between form teachers and the parents of children enrolled in one of the children's clubs in Lower Silesia. The article presents a description of the cooperation between the facility's staff and the parents of two children: Jacek, who had developmental difficulties and problems with social contacts, and Małgosia, in whom selective mutism was suspected. Jacek attended the children's club for a period of two years, while Małgosia, for less than a year. At that time, various turning points occurred in the cooperation of the staff with the children's parents. Cooperation between parents and form teachers is the key to the harmonious development of a young person, and it seems to be particularly important in the case of difficulties in the development and everyday functioning of a child being noticed.

Keywords: cooperation with parents, early education and care institution, nursery, children's club, selective mutism 


\section{Wstęp}

Współpraca pomiędzy rodzicami dziecka a pracownikami instytucji edukacyjnej jest podstawą procesu wspierania dziecka w rozwoju. Wyzwania, jakie stawia przed nami dynamicznie zmieniający się świat sprawiają, że zarówno rola placówki wychowawczej, jak i rodziny muszą ulegać nieustannym aktualizacjom, a ich działania powinny się uzupełniać. Przedmiotem niniejszego artykułu jest prezentacja przebiegu współpracy z rodzicami dwójki dzieci, objętych wczesną edukacją i opieką w klubie dziecięcym: Jacka, który miał trudności rozwojowe i problemy w zakresie kontaktów społecznych oraz Małgosi, u której podejrzewany był mutyzm wybiórczy. Imiona dzieci opisywanych $\mathrm{w}$ niniejszym artykule zostały zmienione. Moim celem jest zwrócenie uwagi na to, jak ważne jest współdziałanie rodziców z wychowawcami, szczególnie w przypadku najmłodszych dzieci, jak istotne są wspólne działania, wzajemne zaufanie i stały kontakt pomiędzy dorosłymi, którzy wychowują dziecko i sprawują nad nim opiekę.

Na terenie Polski zbiorowa wczesna edukacja i opieka nad dziećmi w wieku do lat 3 zorganizowana jest w żłobkach, klubach dziecięcych, a także może być świadczona przez opiekuna dziennego, który może sprawować opiekę nad maksymalnie pięciorgiem dzieci. Zgodnie z „Ustawą o opiece nad dziećmi do lat 3" (Dz.U.2011 Nr 45 poz. 235. http:// prawo.sejm.gov.pl/isap.nsf/DocDetails.xsp?id=WDU20110450235) w żłobku mogą przebywać dzieci od ukończenia 20 tygodnia życia, natomiast w klubie dziecięcym dzieci, które ukończyły 12 miesięcy.

"Ustawa o opiece nad dziećmi w wieku do lat 3" do końca 2017 roku nie poświęcała wiele miejsca tematyce współpracy opiekunów z rodzicami w klubie dziecięcym. Dokument ten zawierał dwa artykuły dotyczące współdziałania rodziców i wychowawców; jeden zobowiązywał prowadzącego zajęcia do współpracy, poprzez prowadzenie konsultacji i udzielanie porad rodzicom $\mathrm{w}$ zakresie pracy z dziećmi, drugi zezwalał rodzicom dzieci uczęszczających do klubu dziecięcego na udział w prowadzonych zajęciach. W myśl nowych przepisów od 1 stycznia 2018 r. w instytucjach wczesnej edukacji i opieki, takich jak żłobek i klub dziecięcy, może działać rada rodziców (http://prawo.sejm.gov. pl/isap.nsf/DocDetails.xsp?id=WDU20110450235). Jest to ważna zmiana, która, zwłaszcza w odniesieniu do dużych instytucji, może mieć wpływ na decyzje podejmowane przez dyrektorów tych placówek. Ta możliwość być może spowoduje większe zaangażowanie rodziców w życie żłobka czy klubu dziecięcego, a tym samym podniesie jakość świadczonych przez nie usług.

\section{Formy współpracy $\mathrm{z}$ rodzicami $\mathrm{w}$ instytucjach wczesnej edukacji i opieki}

Pojęcie współpracy, współdziałania (Banasiak, 2013, za Pilch 1999, s. 35) definiowane jest jako „połączone wspólne, jednoczesne działanie, co najmniej dwóch podmiotów". Wincenty Okoń w Słowniku Pedagogicznym dodaje, że współpraca to „współdziałanie ze sobą jednostek lub grup ludzi, aby osiągnąć jakiś wspólny cel" (Okoń, 1987, s. 346). Mieczysław Łobocki dzieli formy współpracy na indywidualne i zbiorowe (Łobocki, 1999, s. 112). W przypadku żłobka lub klubu dziecięcego współpraca najczęściej przyjmuje charakter indywidualny. Powszechnie znane i stosowane formy współpracy personelu $\mathrm{z}$ rodzicami w instytucjach dla małych dzieci to: zebrania ogólne; indy widualne konsultacje dla rodziców; warsztaty wspierające rodziców w wychowaniu dzieci; codzienna wymiana informacji podczas przyprowadzania i odbierania dziecka; wiadomości przekazywane za pomocą poczty elektronicznej; krótkie wiadomości sms; rozmowy telefoniczne; okresowo przekazywane pisemne informacje dla rodziców, dotyczące rozwoju dziecka; udział rodziców w zajęciach otwartych, a także udział w spotkaniach okolicznościowych; informacje od kierownika klubu, a także wychowawczyń na tablicy ogłoszeń, która jest umieszczona w widocznym miejscu $\mathrm{w}$ instytucji (Telka, 2009).

Każdy wychowawca wypracowuje sobie swój własny styl pracy z rodzicami, ważne sa jego kompetencje komunikacyjne. Marzena Kędra (2011) opisuje cztery fundamentalne zasady prowadzenia twórczej i partnerskiej komunikacji pomiędzy nauczycielami a rodzicami, jakimi są: systematyczność, otwartość, równouprawnienie oraz wzajemna akceptacja i szacunek (Kędra, 2011, s. 1). „Kontakty między nauczycielem a rodzicem mają kilka celów. Jednym z nich jest tworzenie spójnych, bezpiecznych i przyjaznych warunków do edukacji i wychowania dla dziecka, dbałość o jego prawidłowy i harmonijny rozwój. Aby zorganizować jednolite i bezpieczne środowisko, dorośli muszą komunikować się otwarcie i uzgodnić wspólne cele oraz zaplanować działania" (Hernik, Malinowska, 2015, s. 11). Małgorzata Banasiak opisuje badania dotyczące szkoły, która, jak się okazuje, nie jest dla rodziców interesująca sama w sobie, ważna natomiast jest dla nich sytuacja ich dziecka (Banasiak, 2013, za Śliwerski 2004, s. 37). Podobne wrażenie można odnieść, gdy prowadzi się rozmowy z rodzicami dzieci uczęszczających do klubu dziecięcego -często nie interesuje ich współdziałanie dziecka w grupie, jego relacje z rówieśnikami, sytuacyjny kontekst jego aktywności, są natomiast zainteresowani dzieckiem jako takim. Czasem trudno wyjaśnić rodzicowi, że postrzeganie dziecka w instytucji zawsze, w pewnym stopniu, będzie odbywało się przez pryzmat jego funkcjonowania w grupie rówieśniczej. Bywa, że rodzice traktują dziecko wyłącznie jako indywidualną jednostkę, nie powiązaną z grupą rówieśniczą i nastawienie to 
blokuje w rodzicach chęć współdziałania z wychowawcą grupy. Banasiak zwraca uwagę, że rodzice „mają świadomość, iż współpraca jest konieczna i teoretycznie wyrażają chęć do jej nawiązania, ale nie idzie za tym zachowanie potwierdzające taką gotowość" (Banasiak, 2013, s. 44).

Role nauczyciela i rodzica, zwłaszcza w przypadku małego dziecka „zachodzą na siebie”. Dzieci korzystają edukacyjnie i emocjonalnie na tym, gdy rodzice wspierają je, gdy uczestniczą w życiu instytucji. Zaś niektórzy rodzice doceniają, że instytucja okazuje zrozumienie dla codziennych wyzwań z jakimi muszą się borykać, co buduje pozytywne wzajemne nastawienie i zachęca do współdziałania (Karwowska-Struczyk, 2013 za Alexander 2010, s. 74).

Wnikliwą analizę przestrzeni społecznej instytucji wczesnej edukacji i opieki przeprowadziła Lucyna Telka (2009). Autorka prowadziła badania w wielu żłobkach w Łodzi i słusznie podkreśla, że codzienny pobyt dziecka $w$ instytucji, przez kilka lub kilkanaście godzin, wymaga systematycznej, rzetelnej wymiany informacji pomiędzy dorosłymi. Najczęściej występującą formą relacji pomiędzy dorosłymi jest rozmowa -rodzice codziennie przyprowadzają i odbierają dziecko z placówki, zatem dwa razy dziennie jest sposobność do podjęcia rozmowy. Relacjonując wyniki badań dotyczących sposobu komunikacji wychowawców z rodzicami autorka opisuje, że „prawie połowa rodziców postrzegała opiekunki jako osoby stwarzające niekiedy dystans wobec rozmówców lub formułujące wypowiedzi zamykające rozmowę, np. „wszystko było w porządku" (Telka, 2009, s. 130). Na podstawie prowadzonych badań Telka wskazuje na bariery w komunikowaniu się pracowników z rodzicami. Zalicza do nich niskie kompetencje werbalne opiekunek w budowaniu relacji z rodzicami oraz niedostatek kształcenia tej umiejętności społecznej na etapie przygotowania zawodowego, zarówno na uczelniach wyższych, jak również w szkołach policealnych dla opiekunek i podczas organizowanych przez różnorodne instytucje kursów, uprawniających do pracy w zawodzie opiekunki dziecięcej. Autorka opisuje również trudności w relacjach z rodzicami nie angażującymi się w sprawy dziecka w placówce, polegające na tym, że pomimo, iż opiekunka wykazuje gotowość do udzielania informacji, rodzic z różnych powodów pytań nie zadaje. Zdarza się, że rodzice odczuwają niedostatek informacji na temat swojego dziecka w określonym dniu. Chcieliby usłyszeć szczegółową relację o tym co działo się z ich dzieckiem przez cały dzień, zadają różnorodne pytania, a czasem z powodu aktualnej sytuacji w placówce wychowawczyni nie ma możliwości by na te pytania udzielić odpowiedzi. Rejestr pytań wyjątkowo często zadawanych przez rodziców, wyłaniający się z badań Telki, przedstawia się następująco: „czy dziecko zjadło posiłki?”, „czy było grzeczne?”, „,czy i jak długo spało?”. Rzadko pojawia się pytanie: ,jak bawiło się moje dziecko? jak się czuło?". Powodu opisanych sytuacji autorka upatruje w warunkach, w jakich dochodzi do rozmów. „Pierwszy warunek charakteryzuje przestrzeń fizyczna - niewielka szatnia, obecność innych rodziców. Drugi warunek charakteryzowany jest przez czas, mianowicie często zauważa się pośpiech rodziców przy odbieraniu dziecka oraz trudności w pozostawieniu przez opiekunkę grupy dzieci” (Telka, 2009, s. 137). Płynie stąd wniosek, że aby wspierać współpracę wychowawczyń dzieci z rodzicami należy zadbać o czas i miejsce sprzyjające wzajemnej komunikacji.

Małgorzata Karwowska-Struczyk (2017) pisze o wymienianych przez wychowawców dwóch postawach rodziców uczęszczających do żłobka: postawę zainteresowania dzieckiem, przejawiającą się wzajemnym informowaniem o sukcesach rozwojowych dziecka i próbach dopasowania oddziaływań stosowanych w jednym ze środowisk: rodzinnym lub żłobowym oraz postawę, która oznacza brak zainteresowania dzieckiem i traktowanie żłobka jako przechowalni, podczas gdy rodzice oddają się swoim obowiązkom. Autorka pisze też o trudnościach w komunikowaniu się z rodzicami, gdy osiągnięcia rozwojowe dziecka nie są wystarczające: „Niektórzy rodzice takich informacji nie chcą słyszeć, ponieważ wywołuja one dysonans w ich obrazie dziecka i formułowanych przez nich wobec niego oczekiwaniach".

Dziecko znajduje się pod ciągłym wpływem rodziców, nieustannie obserwuje ich zachowania, intuicyjnie czuje, kiedy wszystko jest w porządku. Rodzice są obiektem obserwacji i naśladowania przez dziecko. Pedagodzy muszą być świadomi, że rodzina jest ogniwem łączącym ich ze światem dziecka. Nie jest możliwe realizowanie współczesnych założeń edukacyjnych bez współpracy rodziny i instytucji. Współdziałanie, współpraca, kooperacja, współuczestnictwo, partnerstwo to pojęcia określające wzajemne relacje rodziców i wychowawców (Młynek, 2017, s. 111-112).

W dalszej części tekstu przedmiotem opisu będą dwa przypadki ilustrujące przebieg współpracy z rodzicami dzieci, które zostały objęte wczesną edukacją i opieką w klubie dziecięcym: Jacka oraz Małgosi.

\section{Przypadek Jacka}

Jacek był objęty edukacją i opieką w klubie przez okres dwóch lat, od ukończenia przez dziecko 13 miesięcy, do czasu ukończenia 37 miesięcy. Chłopiec nie wykazywał trudności adaptacyjnych, od pierwszych dni pobytu w klubie dziecięcym był pogodny, otwarty na nowe osoby i sytuacje. W tym początkowym okresie zauważono u niego nadruchliwość i trudności z koncentracją uwagi. Współpraca $\mathrm{z}$ rodzicami w tym czasie polegała głównie na codziennych rozmowach, rodzice bardzo aktywnie uczestniczyli też w dedykowanych dla rodziców warsztatach, m.in. dotyczących adaptacji dziecka w placówce, wspomagania rozwoju psychomotorycznego, wspomagania rozwoju mowy. 
Po okresie 6 miesięcy pojawiły się u chłopca zachowania agresywne względem innych dzieci, a także zauważono brak postępów w rozwoju mowy, dziecko wykazywało nadwrażliwość na dźwięk, dotyk, a także stereotypie ruchowe. Po przekazaniu pierwszego pisemnego sprawozdania, które dotyczyło rozwoju dziecka i zawierało sugestię dotyczącą wizyty chłopca u psychologa, rodzice przyjęli strategię unikania. Starali się możliwie szybko przekazywać syna pod opiekę wychowawcy, nie zadawali też pytań podczas odbioru dziecka z klubu. Poproszeni o spotkanie w ramach konsultacji indywidualnych bardzo chętnie się na nie stawili. W bezpośrednim kontakcie rodzice otwarcie rozmawiali o dziecku, przyjęli informacje o trudnościach i zadeklarowali konsultację z psychologiem integracji sensorycznej. Rodzice zostali wyposażeni w pisemną opinię dotyczącą sposobu funkcjonowania dziecka w grupie i z nią udali się do specjalisty. Psycholog zalecił obserwację i wspieranie rozwoju dziecka poprzez różnorodne zabawy.

Od tego czasu rodzice i pracownicy klubu byli w codziennym kontakcie bezpośrednim, osoba kierująca pracą klubu kontaktowała się z nimi także za pomocą poczty elektronicznej, cały zespół obserwował i wspierał funkcjonowanie chłopca. Sytuacja $w$ kolejnych tygodniach nie ulegała poprawie, agresja w stosunku do dzieci nasilała się, chłopiec też często wycofywał się z relacji lub był natarczywy względem innych: ściskał dzieci, z rozpędu na nie wpadał, kładł się na nie i dociskał do podłoża. W tym czasie dziecko było wspierane przez personel klubu w zakresie poprawy czucia własnego ciała, między innymi poprzez masaże dostosowane do wrażliwości dziecka przez psychologa integracji sensorycznej, jednak nie miało to widocznego wpływu na poprawę funkcjonowania chłopca. Rodzice zostali zapytani (za pośrednictwem poczty elektronicznej) o to, czy psycholog widział potrzebę regularnej terapii, czy zalecił konkretne ćwiczenia, czy wskazał dalsze działanie, np. weryfikację efektów działań po jakimś czasie. Na zadane pytanie rodzice przesłali następującą odpowiedź:

„Proszę o wyjaśnienie o jakie wzmacnianie chodzi, czego wzmacnianie? I o jakq terapię? W poradni integracji sensorycznej psycholog wyraźnie nam wytłumaczyła, że Jacek nie jest upośledzony, ani opóźniony i nie wymaga żadnych specjalnych terapii. Otrzymaliśmy wytyczne co do zalecanych ćwiczeń, stymulacji do rozwoju określonych umiejętności, ale leczenia nasz synek nie wymaga. Bardzo mi przykro, że jest pani innego zdania".

Słowo „terapia” często kojarzy się rodzicom z poważnymi niepełnosprawnościami, nie traktują terapii jako formy wspomagania rozwoju i trudno ich przekonać, że najczęściej w przypadku dziecka jest to zabawa, odpowiednio dobrana przez specjalistę. Powyższa wypowiedź sugeruje obawy rodzica przed niepełnosprawnością, a także trudnościami rozwojowymi. Kiedy rodzice Jacka byli informowani o tym, że dziecko ma niezborność ruchową i czę- sto upada, starali się tłumaczyć, że w domu tego rodzaju sytuacje nie występują, wyrażali jednak chęć współpracy i czekali na wskazówki co mogą zrobić:

„W domu syn nie rzuca się na nas, nie wpada na nas, ani na ściany. Nie wchodzi z nami $w$ takie gwałtowne interakcje, jak $w$ klubie $z$ innymi dziećmi, jakie pani opisuje, typu rzucanie się, kładzenie się na dzieci, zderzanie się. Co do bicia, to zdarza mu się nas uderzyć ręką, albo rzucać $w$ nas zabawkami. Jeśli otrzymamy wskazówki, będziemy je stosować”.

Po kilku spotkaniach indywidualnych i wytłumaczeniu rodzicom, że działania pracowników mają na celu wyłącznie polepszenie funkcjonowania Jacka, udało się zyskać przychylność rodziców i zmobilizować ich do działania. W następstwie podjętych przez nich decyzji w niedługim czasie dziecko miało uporządkowany plan dnia, podczas snu stosowano kołdrę obciążeniową, rodzice wykonywali systematycznie zalecane masaże, a także wspomagali rozwój mowy syna, zgodnie z zaleceniami logopedy.

Pod koniec trzeciego roku życia dziecka (był to zarazem ostatni etap uczęszczania Jacka do klubu) pojawiła się kolejna trudność. Pewnego dnia mama, za pośrednictwem poczty elektronicznej, napisała wiadomość, w której poprosiła o poradę i pomoc w następującej sytuacji:

„Jacek nie chce taty przy zasypianiu, czytaniu i opowiadaniu bajek na dobranoc, chce zasypiać tylko ze mna. Często też protestuje, by mąż się z nim bawił i woła mnie, męża odgania, mówi by wyszedł z pokoju. O wiele lepiej wygląda to na podwórku, gdy wychodza razem na spacer i np. razem grają $w$ piłkę, nie protestuje też przy porannym wychodzeniu z domu do klubu. Czy to normalne? Co możemy zrobić?".

W związku z poprzednimi obserwacjami trudności w funkcjonowaniu społecznym, rodzice otrzymali zalecenie konsultacji ze specjalistami, ale również pracy z dzieckiem na zasadzie uprzedzania go o nowych wydarzeniach, oswajania z osobą taty w różnych sytuacjach, za które dotychczas była odpowiedzialna wyłącznie mama. Choć poziom rozwoju mowy Jacka w wieku 3 lat był na etapie dziecka półtorarocznego, to dzięki intensywnej pracy, zarówno w klubie, jak również w domu, nastąpił wyraźny postęp w rozwoju komunikacji werbalnej i niewerbalnej. Rodzice zadecydowali, że odłożą konsultacje ze specjalistami do czasu rozpoczęcia edukacji przedszkolnej i wtedy, w przypadku, jeśli trudności $\mathrm{w}$ funkcjonowaniu $\mathrm{w}$ grupie będą się utrzymywały, podejmą specjalistyczną diagnozę zaburzeń.

Kiedy Jacek rozpoczął edukację przedszkolną rodzice pozostali w kontakcie z pracownikami klubu. Początkowo opowiadali o trudnej adaptacji chłopca w przedszkolu, zaznaczyli też, że nauczycielki zwracały uwagę na opóźnienie rozwoju mowy oraz trudności z koncentracją, po kilku miesiącach przekaz o funkcjonowaniu dziecka w nowym miejscu nabrał pozytywnego wymiaru. Mama Jacka podczas rozmowy telefonicznej, z radością opowiadała o wyciszeniu syna, rozwoju mowy i jego dojrzałości. 
Podkreślała, że trudności, które były wcześniej, aktualnie już nie występują. Ocena faktycznego funkcjonowania w przedszkolu nie jest możliwa, jednak opierając się na przekazie mamy można stwierdzić, że podjęte wspólne działania wychowawczyń oraz rodziców pomogły dziecku w jakimś zakresie przezwyciężyć trudności w funkcjonowaniu społecznym.

\section{Przypadek Małgosi}

Opis współpracy z rodzicami Małgosi dotyczy okresu kilku miesięcy, począwszy od ukończenia przez dziecko 21 miesięcy. Dziewczynka w pierwszych dniach pobytu w klubie była bardzo zainteresowana otoczeniem, okres adaptacyjny przebiegał dość spokojnie. Rodzice zgłosili na samym początku, że dziecko jest nieśmiałe i obserwują spory dystans wobec dorosłych, duży lęk przed mężczyzna$\mathrm{mi}$, nawet z najbliższej rodziny, choć sytuacja nie dotyczyła ojca. W tym początkowym okresie Małgosia mało się odzywała, szczególnie do dorosłych. Jeśli coś mówiła, to wyłącznie do dzieci lub do siebie podczas zabawy. Pytana o cokolwiek spuszczała głowę i bawiła się rączkami.

Współpraca z rodzicami w tym czasie polegała głównie na codziennych rozmowach. Wychowawczynie przekazywały informacje o ograniczonej komunikacji z dzieckiem, rozmowy dotyczyły też podejrzenia mutyzmu wybiórczego. Osoby z mutyzmem wybiórczym potrafią mówić, chcą mówić, ale $\mathrm{w}$ pewnych sytuacjach nie są $\mathrm{w}$ stanie mówić (Bystrzanowska, 2017, s. 7-12). Po kilku tygodniach pobytu Małgosi w klubie, rodzice podczas rozmowy z kierownikiem klubu oświadczyli, że wybierają się na szkolenie dotyczące mutyzmu wybiórczego. Zaangażowanie we wspieranie córki było imponujące, w związku z tym, że trudności z lękiem przed mówieniem występowały już wcześniej w rodzinie ojca, motywacja rodziców do podjęcia profilaktyki była jeszcze większa. Mutyzm wybiórczy należy do zaburzeń lękowych, które mogą mieć podłoże genetyczne z uwagi na poziom neuroprzekaźników.

Po szkoleniu, na którym rodzice szczegółowo omówili z prowadzącą przypadek Małgosi, przekazali pracownikom klubu wytyczne co do sposobu prowadzenia wspomagania. Osoba kierująca pracą klubu uważnie przeanalizowała literaturę, a także zalecenia w niej zawarte i, bazując na własnym doświadczeniu i obserwacjach dziecka, ustaliła wskazówki dla personelu. Były to m.in. brak presji mówienia, metoda „od chóru do solo" (ibidem, s. 95), zamiana pytań otwartych na zamknięte. Rodzice mieli jednak swoje wyobrażenie co do sposobu wsparcia, nalegali na spotkania w klubie z jedną osobą -koordynatorem terapii mutyzmu Małgosi. Jest to metoda nazwana nieformalnym sliding-in $\mathrm{i}$ jest polecana przez Marię Bystrzanowską dla dzieci do 6-7 roku życia (ibidem, s. 69). Metoda ta polega na stopniowym rozszerzaniu grona osób, z którymi dziecko rozmawia, najpierw dziecko jest $\mathrm{z}$ rodzi- cem, następnie dołącza terapeuta i on wprowadza kolejne osoby. Z uwagi na organizację pracy klubu, m.in. fakt, że różne wychowawczynie są obecne o różnych porach, trudne było wyznaczenie jednej osoby, która mogłaby pełnić taką funkcję. Ponadto wytyczne mówią, że nauczyciel (w przypadku klubu dziecięcego wychowawca) nie powinien być koordynatorem (ibidem, s. 79). Mając na uwadze informację od rodziców o możliwej predyspozycji genetycznej, a także to, że Małgosia nie miała dodatkowych symptomów niepokoju (jadła posiłki, z każdym dniem jej komunikacja niewerbalna była bardziej rozwinięta) kierownik klubu brał pod uwagę również inne przyczyny braku werbalizacji, również natury lękowej, ale niekoniecznie mutyzm wybiórczy.

Mimo, że kierownik klubu to jednocześnie logopeda, bardzo zaangażowany w przypadek Małgosi, można było mieć poczucie, że rodzice nie byli przekonani do działań w klubie. Odczucia zostały niejako potwierdzone po miesiącu, kiedy wpłynęła, za pośrednictwem poczty elektronicznej, wiadomość od ojca Małgosi o następującej treści: „W związku z tym, że współpraca komplikuje się bardziej niż można było na początku przypuszczać, prosiłbym o spotkanie, kiedy można by było spokojnie porozmawiać na ten temat?”. Dłuższe spotkanie i wyjaśnienie metod pracy z dzieckiem wydawało się być wtedy najlepszym rozwiązaniem.

To był moment zwrotny we współpracy z rodzicami Małgosi. Zostały wyjaśnione wątpliwości, uargumentowane stanowisko specjalisty i przyjęto wspólne założenia. Małgosia z każdym dniem coraz bardziej się otwierała, po dwóch miesiącach prowadziła prosty dialog z większością wychowawczyń, w kolejnym miesiącu sama inicjowała rozmowy. Wciąż nie mówiła dużo, ale swobodnie się czuła, pozostawała w kontakcie wzrokowym, rozmawiała z wychowawczyniami nawet wtedy, kiedy w klubie pojawił się ktoś obcy, np. rodzice innych dzieci. Działania terapeutyczne i profilaktyka zaburzeń lękowych były kontynuowane i z każdym dniem odnotowywano dalsze postępy Małgosi w zakresie komunikacji werbalnej. Momentem kluczowym dla sukcesu w pracy z Małgosią była bezpośrednia rozmowa kierownika klubu z jej rodzicami o ich wątpliwościach i zbudowanie atmosfery wzajemnego zaufania pomiędzy nimi i personelem instytucji. W związku z tym, że rodzice pozostali w kontakcie z pracownikami klubu, wiadomo, że dziewczynka dobrze poradziła sobie z okresem adaptacji na kolejnym etapie edukacji: w przedszkolu. Nawiązała kontakty społeczne zarówno z dziećmi jak również z nauczycielami i komunikowała się z innymi od początku werbalnie.

\section{Wnioski}

Dwa przedstawione przypadki pokazują, jak istotna jest współpraca rodziców z personelem instytucji, do której uczęszcza dziecko. Wydaje się 
ona być jeszcze ważniejsza, jeśli dotyczy dziecka do trzeciego roku życia, tym bardziej, jeśli występują u niego jakieś trudności rozwojowe. Tak było w przypadku Jacka i Małgosi, którzy wymagali wsparcia, zarówno ze strony instytucji, jak również ze strony rodziców. Wspólne działania rodziców i personelu przyspieszyły rozwój dzieci -opinię potwierdziły dwie strony.

Współcześnie dzieci coraz częściej wymagają różnorodnych form wspomagania czy terapii, opóźnianie momentu rozpoczęcia takich oddziaływań przez rodziców przyczynia się do wydłużenia czasu udzielenia dziecku koniecznej pomocy. Nieufność rodziców wobec pedagogów, ich chęć odsunięcia problemu, a czasem nadmierne skupienie się na jednym rozwiązaniu, na ogół nie prowadzi do polepszenia sytuacji dziecka. Wspólne działanie triady: dziecko-rodzic-wychowawca buduje w dziecku poczucie bezpieczeństwa, które stanowi podstawę harmonijnego rozwoju. Nie ulega wątpliwości, że o dzieciach decydują rodzice, osoba prowadząca instytucję wczesnej edukacji i opieki może jedynie szukać sposobów zachęcenia ich do współpracy. Przypadki
Jacka i Małgosi wskazują, jak ważne jest wzajemne zaufanie i współpraca rodziców i wychowawczyń dziecka w placówce i potwierdzają, że dzięki tej współpracy można pomóc dziecku pokonać pojawiające się, przejściowe trudności rozwojowe.

Rola wychowawcy w instytucji wczesnej edukacji i opieki jest niezwykle istotna. Rodzic, który często nie dysponuje rozszerzoną wiedzą o rozwoju dziecka i nie ma zbyt wielu możliwości obserwowania jak funkcjonuje dziecko w środowisku rówieśniczym, może nie zdawać sobie sprawy z jego trudności i potrzeby wspomagania rozwoju dziecka. Kluczowe jest indywidualne podejście do rodzica i wygospodarowanie czasu na rozmowę. Uwagi dotyczące dziecka, które pojawiają się „przy okazji” i nie są wyjaśnione przez wychowawcę, mogą być odebrane jako forma ataku i najczęściej pojawia się wtedy rodzicielska postawa obronna lub wręcz postawa unikajaca. Stały kontakt wychowawcy z rodzicem i wspólne podążanie za dzieckiem to w opinii autorki niniejszego artykułu jedyna właściwa droga by efektywnie wspierać dzieci, zwłaszcza te, które nie ukończyły jeszcze trzech lat.

\section{Literatura:}

1. Banasiak, M. (2013). Współpraca rodziców ze szkoła w kontekście reformy edukacji w Polsce, Toruń: Repozytorium Uniwersytetu Mikołaja Kopernika. Pobrane z: https://repozytorium.umk.pl/bitstream/ handle/item/526/Małgorzata\%20Banasiak\%20ksiązka.pdf

2. Bystrzanowska, M. (2017). Mutyzm wybiórczy - Poradnik dla rodziców, nauczycieli i specjalistów, Kraków: Oficyna Wydawnicza „Impuls”.

3. Hernik, K., Malinowska, K. (2015) Jak skutecznie współpracować i komunikować się z rodzicami i społecznościq̨ lokalnq. Poradnik dla nauczycieli i dyrektorów. Warszawa: Instytut Badań Edukacyjnych.

4. Karwowska-Struczyk, M. (2013). Rodzice w przedszkolu - balast czy koło ratunkowe? W: E. Jaszczyszyn, J., Z. Górnikiewicz (red.), Środowiskowe i językowe konteksty edukacji dziecka w rodzinie, przedszkolu i szkole (s.59-91). Warszawa: Polski Komitet Światowej Organizacji Wychowania Przedszkolnego (OMEP).

5. Karwowska-Struczyk, M. (2017). Kim są dzieci, jak się uczą? - jakościowa analiza wywiadu z wychowawcami w żłobku. Nauki o wychowaniu. Studia Interdyscyplinarne, 2(5), 65-83. http://dx/doi.org/10.18778/2450-4491.05.05

6. Kędra, M. (2011). Włączanie rodziców w edukację dzieci. Gniezno: Wydawnictwo PSAPCF.

7. Łobocki, M. (1999). ABC wychowania. Lublin: Wydawnictwo UMCS.

8. Młynek, P. (2017) Współpraca rodziców i nauczycieli - charakter, oczekiwania i uwarunkowania. Rozprawa doktorska przygotowana pod kierunkiem naukowym Dr hab. Ewy Jarosz. Katowice: Uniwersytet Śląski w Katowicach, Wydział Pedagogiki i Psychologii.

9. Okoń, W. (1987). Słownik pedagogiczny. Warszawa: Wydawnictwo Naukowe PWN.

10. Telka, L. (2009). Przekształcanie przestrzeni społecznej placówki. Studium społeczno-pedagogiczne na przykładzie żłobków. Łódź: Wydawnictwo Uniwersytetu Łódzkiego.

11. Ustawa z dnia 4 lutego 2011 r. o opiece nad dziećmi w wieku do lat 3, Dz.U.2011 Nr 45 poz. 235. http://prawo.sejm.gov.pl/isap.nsf/DocDetails.xsp?id=WDU20110450235 